\title{
HOMENAGEM AO PROFESSOR PHLLMENO JOAQUIM DA COSTA
}

- "Quando a vida deixa um corpo, será isso a morte?"

Tantos já se debruçaram sobre esta dúvida, e ninguém ao certo sabe a resposta! Philomeno Joaquim da Costa, meu pai e de meus três irmãos Paulo Plínio, Antonio Augusto e Mário Marcos, professor de tantos outros, se voltasse a tempo, com seu amor pela polêmica de velho advogado, também participaria desse debate, ainda que seus temas preferidos fossem pragmáticos, não-filosóficos. Qual sua opinião? Creio que a tenho, a partir de suas palavras e em função de sua experiência de vida.

Philomeno teve um irmão mais velho que faleceu com tenra idade. A mãe Melania Pinelli da Costa, de Bolonha, quis evitar novos riscos, prometendo o nome do santo de seu nascimento. Santa Philomena de 10 de outubro de 1904 lhe poupou dos piores espinhos ao largo de seus longos 91 anos de vida, até novembro de 1995, mas não de todas as asperezas, as mesmas que forjaram seu caráter. Sem jamais haver perdido o $1^{\circ}$ lugar no Grupo Escolar, apesar do esforço de seu colega e grande amigo, também notável advogado deste Foro de São Paulo, Eduardo Pellegrini, que na escola seguia brilhante $2^{\circ}$ posto, Philomeno Joaquim da Costa aos catorze anos viu-se na condição de arrimo de família. Seus pais faleceram mais cedo, o que não nos permitiu conhecer os avós, em especial o capitão José Joaquim da Costa, comandante do Corpo de Bombeiros, cuja memória e origem humilde nos faz orgulhosos. Consciente, foi só à luta em pequenos empregos, para sustentar quatro irmãs (Maria, Adelaide, Rosalina e Sílvia), porque então era desonroso que as mulheres trabalhassem.

Formou-se contabilista na Escola de Comércio Álvares Penteado, levantando o Prêmio Carvalho de Mendonça pela sina de ter sido o melhor aluno! Era 1921 quando foi à rua trabalhar com as partidas dobradas de Frà Lucca, esforçado guarda-livros de sol a sol. Teve a sorte de encontrar pela frente um mau patrão. Na dialética da vida que abate os mais fracos e incomoda os mais fortes, não tardou a se rebelar, batendo às portas da velha e sempre nova Academia do Largo de São Francisco. Em suas arcadas de paz e de luzes formou-se em 1929, advogado de n. 721 da OAB-SP

Mas logo voltou à Casa, premido pelo dever cívico de São Paulo Constitucional. Também deixou a folha dobrada... Escapou de morrer em 1932, trazendo na testa direita o milimétrico raspão de uma bala de fuzil. Participou do 
Batalhão 14 de Julho na linha de frente sul (Itapetininga e Itapeva), dormindo no chão, de preferência sobre as lápides e muros de cemitérios protegidos, aonde contava pisar na terra fosfórica de cadáveres antigos -- para mim sua estória mais fantástica -- terra que se iluminava sob as botas úmidas em círculos fosforescentes de renascimento.

Apenas se casou aos 43 anos, no distante 1947, formando família quase no momento em que todos a tem criada. Yolanda Sá Leite Orcesi, Orcesi da Costa, companheira e mãe, pôs termo às suas energias dispersas, viagens, George V (ou seria Príncipe de Gales), cavalos na Hípica, título do Harmonia e falta de títulos do Corinthians, camarotes no Municipal, Copacabana, Montrachet. Foi ela que desviou seu foco de luz para dentro de uma nova família que continua forte como o patriarca, oito netos, um casal de cada filho. Marido constante, sempre às quartas $\mathrm{e}$ sábados cinema ou teatro, depois uma pizza no Gigetto, em julho viagens ("conhecer primeiro o Brasil"). Certa vez me perguntaram: -- "Será ele tão bravo como pai do que como professor?" Como nunca havia pensado demorei-me segundos antes de responder: -- "Ele não é bravo, é justo" Hoje estou certo de que foi modelo de pai, liberal quando tudo caminhava bem, intransigente quando constatava desvio de rota. Como é comum os pais de hoje adotarem o comportamento comodista e relaxado de avós.

Presidente do Sindicato dos Contabilistas, diretor da Revista dos Tribunais aonde aprendeu Direito taquigrafando os votos dos desembargadores (não havia xerox ou computadores), inumeráveis artigos, críticas bibliográficas (de que gostava porque equivalia a estudar), pareceres e comentários, começou advogando num dos melhores escritórios paulistanos, titulado pelo Professor Noé Azevedo. Braço direito do sereno mestre, conta-nos do espírito da década de 50: -- "Uma vez, precisando complementar o dinheiro para compra da casa da Rua José Getúlio, pedi ao Noé uma quantia" Ao que lhe respondeu: -- "Philó, pegue no cofre aquilo de que você precisa" E mais não indagou, nem foi conferir...

Delegado a diversas conferências, vice-presidente do Instituto dos Advogados, iniciou a lecionar no Mackenzie, depois brevemente na Universidade de Campinas, até a defesa de tese no Largo de São Francisco, em 1956, Autonomia do Direito Comercial, tornando-se livre-docente, e quase a mesmo tempo livreadvogado, montando sua própria banca. Em 1962 assume a tão almejada cátedra de Direito Comercial na Universidade de São Paulo (Operações da Anônima com as Ações de seu Capital), recebendo posteriormente o título de professor emérito. É 
diretor da Faculdade de Direito e mais adiante, no ano de 1974, reitor da Universidade Mackenzie. Na frutífera década de 80 assume a presidência do Instituto Brasileiro de Direito Comercial Comparado e Biblioteca Tullio Ascarelli, desenvolvendo com seus pares profícuo trabalho de fomento e debate jurídico.

Pelas auto-estradas da vida (não era como o rio que desce a colina escolhendo o melhor trajeto) foi modelo de correção moral e devoção, à família, à causa do magistério, à advocacia. Tinha paixão pela Faculdade, pelo estudo diário, longas horas, para os demais mortas aos sábados e domingos, 50 mil fichas que antecipavam a ordem dos computadores. E tudo com um entusiasmo natural, uma disciplina inflexivel, inclusive nos esportes, todas as manhãs a natação ainda que gélida, longas caminhadas com Yolanda pela madrugada de uma Paulicéia menos desvairada. Muitos alunos dele guardaram mágoas, por sua dureza na hora das notas, mas era afinal isso que ele sempre quis deixar como exemplo: força, forçade-vontade, força fisica e moral. Tinha o defeito de não compreender a fraqueza, a falta de vontade de vencer... Gostava de citar um pensamento francês: "il n'y a pas des accomodements au ciel" (há também a versão positiva), utilizando-a no sentido da necessidade de resolver na Terra as dificuldades.

Forte sim é a palavra que a ele melhor se aplica. Fortaleza. Forte como advogado, típico battonier das causas injustas. Nelas se entregava não como o general que investe e recua, que ataca pelos flancos mas se protege, explora e incute, mas diretamente como o cavaleiro das justas medievais de lança em riste, num duelo com a única opção de matar ou morrer. Numa ocasião, um magistrado, na mesa de bar do Jóquei Clube, confessou a dois amigos que daria voto favorável a um cliente de Philomeno Joaquim da Costa. Posteriormente mudou de opinião, proferindo voto a favor do Governo do Estado, que então vencia por 2 a 1. Juiz do Tribunal de Alçada Civil, fora coincidentemente nomeado para o Tribunal de Justiça, aguardando apenas o julgamento dos embargos infringentes para assumir a investidura. Junto aos embargos, Philomeno Costa argüiu a suspeição desse magistrado.

O Plenário lotado, alguns alunos a que havia avisado, platéia espremida. Sustentando oralmente o incidente, Philomeno Joaquim da Costa se colocou obliquamente na Tribuna, encarando na direção do juiz sob suspeição. Era um muro enfrentando a corrupção velada e o poder político desvelado. Palavras naturalmente ásperas, por mais que entremeadas de vênias. Ou faltaram algumas vênias? Talvez, recordo-me apenas de como eram convincentes. A um ponto o juiz 
presidente interviu com uma advertência, solicitando decoro. Uma resposta, soou a campainha, várias vozes e uma tréplica final:

“-- Vossa Excelência não me cassará a palavra. É direito do advogado" gritava da Tribuna, investindo contra o suspeito.

“-- Ordem no Tribunal" replicava o juiz, em idêntico tom de voz.

Gritos e sussurros, juízes que intervinham por ter algo a dizer, campainhas e sinos, algo próximo da balbúrdia.

“-- Está suspensa a sessão”, interrompeu o presidente.

Após o recesso, o Tribunal retomou a sessão; Philomeno Joaquim da Costa concluiu sua oratória de modo mais calmo. O magistrado recusou a suspeição, historiou sua carreira imaculada, afastou a relação de causa e efeito decorrente de sua investidura no Tribunal de Justiça, alguns de seus pares devem tê-la pensado surpreendente, porém votaram por unanimidade a seu favor, como aliás recomenda o espírito de corpo diante de acusação tão grave. Mas a sorte fora lançada. Naquele mesmo dia, no exame do mérito, na sessão cameral, os grandes juízes Macedo Costa e Evaristo dos Santos votaram contra o rolo compressor do Governo. Vitória de 3 a 2! Prevaleceu a independência, mas é razoável imaginar se com menor determinação a causa (e toda uma Universidade) não estaria perdida. $\mathrm{O}$ que me surpreendeu na volta daquele dia à casa (ainda morava com os pais) foi uma confissão: "-- se tivéssemos perdido iriamos a Brasilia contra esse juiz suspeito" Não teria desistido; tinha o corajoso depoimento (aquele do balcão do bar) de uma importante testemunha, professor da Faculdade de Direito, com as mesmas iniciais $P J C$.

"-- Não me cassem a palavra" Sim, esta é uma das razões pelas quais acredito que meu pai não recusaria participar do filosófico debate sobre a eternidade da alma. Quando a vida deixa um corpo, não é a morte. Mas será que ele responderia 'não'? Apenas o Investigador do universo poderia saber ao certo. Philomeno Costa, ateu por convicção, ainda que cristão por comportamento, era positivista, confiante em si, não pensava na eternidade. Terá ele nos seus últimos e poucos sofridos dias, encontrado para a orfandade da dor o alívio da prece? Aliás, quantas formas de prece não conhece o Criador?

Preferia registrar aqui o não, mas Philomeno Joaquim da Costa teria respondido sim. Talvez me critique a mãe católica por não atenuar a versão final, interpretar um gesto qualquer para direta sagração, ante o risco das trevas. É possível $乞$ nem seria menos nobre admitir, porque não penso que a humildade e 0 
reconhecimento sejam virtudes menores. Contudo, prefiro não cometer o equívoco de especular com sua personalidade e memória. Creio sinceramente que Philomeno Joaquim da Costa não abdicou de suas conviç̧ões, até porque teria argumentos valiosos em favor de seu comportamento moral, exemplo e obra, bem ao contrário dos cristãos que perante o cali-se da morte, tudo esperam solver à undécima hora.

Não há mal algum nessa verdade. Mestre, gostava da ousadia e da divergência, quando o interlocutor sabia se impor. Portanto, dele hoje discordo, eu que tanto me identifico com ele, que tanto brigamos e sempre continuamos juntos. E por quê não, um filho deve saber quando divergir do pai. Também sou advogado e com ele aprendi a não perder a independência e a não deixar me cassarem a palavra. Penso que não, que quando a vida deixa um corpo NÃO é a morte. Nem me refiro apenas aos livros, às lições, à memória, à família reunida, aos quatro filhos-homens que ele se orgulhava de mostrar, erguendo da liça o escudo que só o tempo implacável the poderia derrubar.

Refiro-me sim à penetrabilidade através da morte. Prefiro acreditar, ainda que só por fé, no encontro temporal, minha mãe a se reunir com ele além de nosso irrelevante firmamento, almas gêmeas a comprovar o ditado de que os opostos se atraem, e mesmo eu, mais adiante, sem pressa porque o tempo é infinito. Satisfeito de o reconhecer numa Tribuna, em pé, com sua velha têmpera, depois de tanto tempo como se nada de anormal houvesse acontecido... "isso não é nada" Quase posso ver como uma daquelas eternas luzes fosforescentes dos cemitérios de barro de 32, esvoaçando e renascendo em direção a outros ambientes inimagináveis, a comprovar que não era mesmo a morte, dele discordando mais uma vez no gesto excessivamente emocional, para afinal estreitá-lo num forte abraço. 



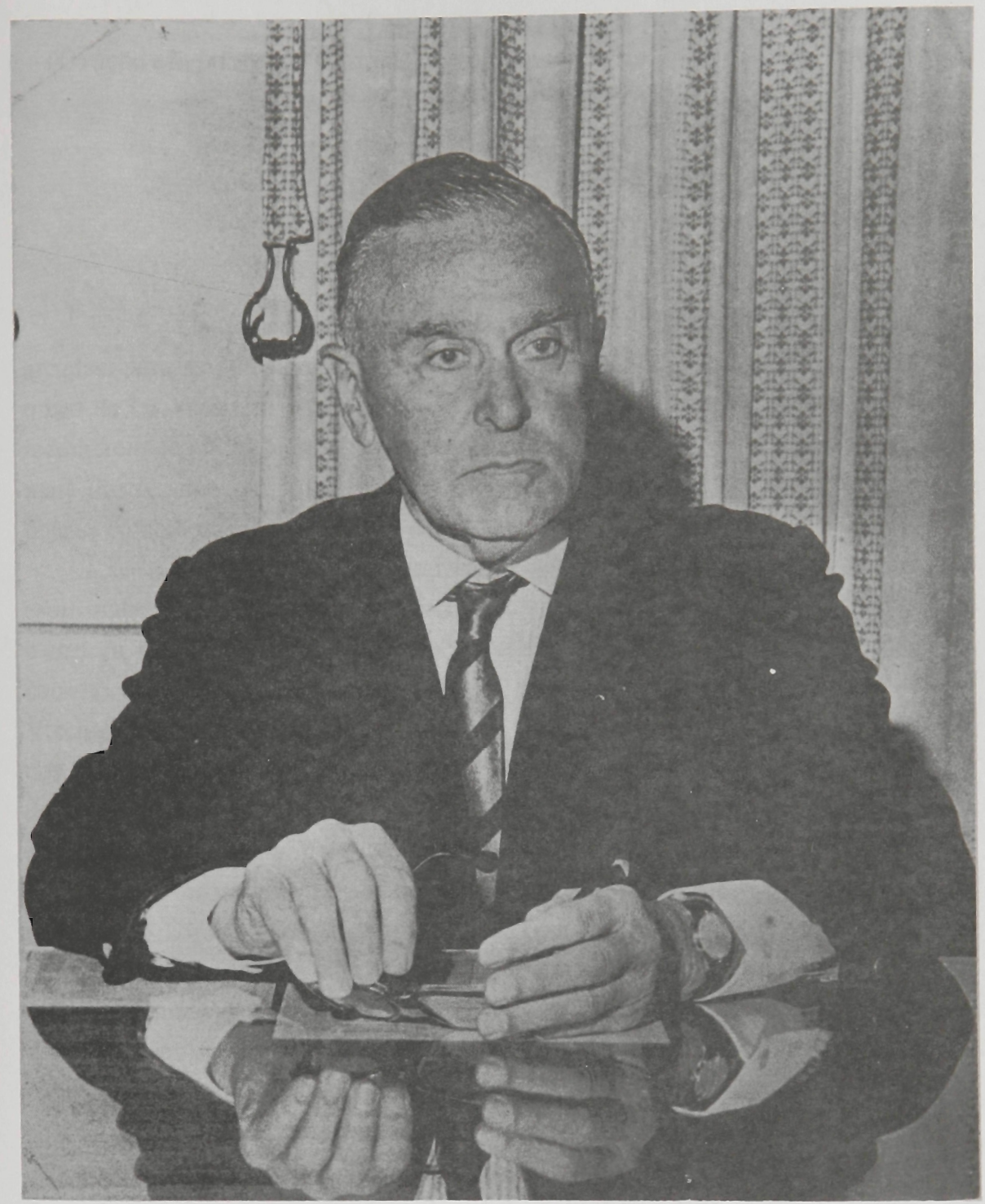

Professor Philomeno Joaquim da Costa 